\title{
Marketing of Higher Education Services: Students' Opinion towards Repositioning Public Universities for Global Competitiveness
}

\author{
Andy Fred Wali ${ }^{1}$, Emmanuel A. Amangala ${ }^{2}$ and Obabuike Ikeni Nkpurukwe $^{3}$ \\ ${ }^{1 \& 3}$ Department of Business Administration, Federal University Wukari, Taraba State, Nigeria. \\ ${ }^{2}$ Department of Marketing, Niger Delta University, Bayelsa State, Nigeria.
}

CITATION: Wali, Andy Fred; Amangala, Emmanuel A. and Nkpurukwe, Obabuike Ikeni (2020), "Marketing of Higher Education Services: Students' Opinion towards Repositioning Public Universities for Global Competitiveness", MERC Global's International Journal of Management, Vol. 8, Issue 3, pp. 125-132.

ARTICLE HISTORY: Submitted: March 20, 2020, Revision received: May 12, 2020, Accepted: May 26, 2020

ARTICLE TYPE: Research paper

\begin{abstract}
This study investigates the marketisation of public universities drawing from Nigeria students' learning experiences. The study adopted the interpretive paradigm and the population comprises students from 4 public universities in two states in South-South Nigeria. The purposive sampling was used to identify three categories of students in each of these universities, which is undergraduate, postgraduate (Master and Doctoral students) and 4 focus group interviews were conducted. Content and thematic template analysis techniques were employed to analyse the data with the use of NVivo 11. The study revealed that students' learning experiences in these sampled institutions were unsupportive of global best practices for international marketisation of academic services of public universities in Nigeria. The key themes that validate these experiences include: infrastructure deficit, poor tutors' commitment; unprofessionalism and inadequate training amongst others and recommendations are suggested in line with these themes.
\end{abstract}

KEYWORDS: Marketisation, Students learning, Public universities, Nigeria.

\section{BIBLIOGRAPHY}

1. Adler, P. and Adler, P. (2012), "Expert voice", in Saunders, M.N.K. and Townsend, K. (2016) 'Reporting and justifying the number of interview participants in organization and workplace research', British Journal of Management, Vol. 27, Issue 4, pp. 836-852.

2. Ambler, T.; Harvey, M. and Cahir, J. (2016), "University academics' experiences of learning through Mentoring", Aust. Educ. Res., Vol. 43, pp. 609-627.

3. Andy-Wali, H.A. and Wali, A.F. (2018), "Lecturers' leadership practices and their impact on students' experiences of participation with implications for marketing higher education services", Journal of Higher Education for the Future, Vol. 5, Issue 1, pp. 40-60.

4. Arena, M.; Arnaboldi, M. and Azzone, G. (2010), "Student perceptions and central administrative services: the case of higher education in Italy", Studies in Higher Education, Vol. 35, Issue 8, pp. 941959.

5. Biasutti, M. (2011), "The student experience of a collaborative e-learning university module", Computers \& Education, Vol. 57, pp. 1865-1875.

6. Block, B. and Khvatova, T. (2017), "University transformation: Explaining policy-making and trends in higher education in Russia", Journal of Management Development, Vol. 36, Issue 6, pp. 761-779.

7. Blume, L. E. and Easley, D. (2008), Rationality - the new palgrave dictionary of economics, $2^{\text {nd }}$ edition.

8. Brinkmann, S. and Kvale, S. (2015), Interviews, 3rd ed., Sage Publications, London.

9. Brown, A.; Rich, M. and Holtham, C. (2014), "Student engagement and learning Case study of a new module for business undergraduates at Cass business school", Journal of Management Development, Vol. 33, Issue 6, pp. 603-619. 
10. Campbell, J. and Li, M. (2008), “Asian Students' Voices: An Empirical Study of Asian Students' Learning Experiences at a New Zealand University", Journal of Studies in International Education, Vol. 12, Issue 4, pp. 375-396.

11. Cardoso, S.; Carvalho, T. and Santiago, R. (2011), "From Students to Consumers: reflections on the marketisation of Portuguese higher education", European Journal of Education, Vol. 46, Issue 2, pp. 271-284.

12. Chang, T.; Bai, Y. and Wang, T. (2014), "Students' classroom experience in foreign-faculty and localfaculty classes in public and private universities in Taiwan", High Educ., Vol. 68, Issue 207-226.

13. Creswell, J. (2007), Qualitative Inquiry and Research Design: Choosing among Five Approaches, $2^{\text {nd }}$ ed., Sage Publications, Thousand Oaks, CA.

14. Diseth, A.; Pallesen, S.; Brunborg, G.S. and Larsen, S. (2010), "Academic Achievement among First Semester Undergraduate Psychology Students: The Role of Course Experience, Effort, Motives and Learning Strategies", Higher Education, Vol. 59, Issue 3, pp. 335-352.

15. Douglass, J. A.; Thomson, G. and Zhao, C. (2012). "The learning outcomes race: the value of selfreported gains in large research universities", Higher Education, Vol. 64, Issue 3, pp. 317-335.

16. Goyal, Varsha (2019), "Management Education: Perceived Role of Social Media", MERC Global's International Journal of Management, Vol. 7, Issue 2, pp. 141-146.

17. Hall, S. (2015), "Geographies of marketisation in English higher education: territorial and relational markets and the case of undergraduate student fees", Area, Vol. 47, Issue 4, pp. 451-458.

18. Hardy, I. (2015), "Education as a 'risky business': Theorising student and teacher learning in complex times", British Journal of Sociology of Education, Vol. 36, Issue 3, pp. 375-394.

19. Holmes, D.; Zayas, L. E. and Koyfman, A. (2012), "Student Objectives and Learning Experiences in a Global Health Elective", J. Community Health, Vol. 37, pp. 927-934.

20. Judson, K. M. and Taylor, S. A. (2014), "Moving from marketisation to marketing of higher education: The co-creation of value in higher education", Higher Education Studies, Vol. 4, Issue 1, pp. 1-18.

21. King, N. and Horrocks, C. (2010), Interviews in Qualitative Research, Sage Publications, Ltd, London.

22. Kong, C. (2008), "Classroom learning experiences and students'perceptions of quality of school life", Learning Environ Res., Vol. 11, pp. 111-129.

23. Kosnik, R. D.; Tingle, J. K. and Blanton, E. L. (2013), "Transformational Learning In Business Education: The Pivotal Role of Experiential Learning Projects", American Journal of Business Education, Vol. 6, Issue 6, pp. 613-630.

24. McGregor, K. K.; Langenfeld, N.; Van Horne, S.; Oleson, J.; Anson, M. and Jacobson, W. (2016), "The University Experiences of Students with Learning Disabilities", Learning Disabilities Research \& Practice, Vol. 31, Issue 2, pp. 90-102

25. Molesworth, M.; Nixon, E. and Scullion, R. (2019), "Having, being and higher education: the marketisation of the university and the transformation of the student into consumer", Teaching in Higher Education, Vol. 14, Issue 3, pp. 277-287.

26. Morgan, D.L. (2010), "Reconsidering the role of interaction in analysing and reporting focus groups", Qualitative Health Research, Vol. 20, Issue 5, pp. 718-722.

27. Newman, S. and Jahdi, K. (2009), "Marketisation of education: Marketing, rhetoric and reality", Journal of Further and Higher Education, Vol. 33, Issue 1, pp. 1-11.

28. Rienzo, T. and Han, B. (2011), "Does ERP Hands-On Experience Help Students Learning Business Process Concepts?”, Decision Sciences Journal of Innovative Education, Vol. 9, Issue 2, pp. 177-207.

29. Sakore, Vaishali B. and Pahurkar, Rajesh N. (2019), "A Study on Satisfaction of Students towards eGovernance services of Savitribai Phule Pune University with special reference to Convocation Degree Certificate Service”, MERC Global's International Journal of Management, Vol. 7, Issue 1, pp. 76-82.

30. Sandal, A. K.; Smith, K. and Wangensteen, R. (2014), "Vocational Students Experiences with Assessment in Workplace Learning", Vocations and Learning, Vol. 7, Issue 241-261.

31. Saunders, M.N.K. and Townsend, K. (2016), "Reporting and justifying the number of interview participants in organization and workplace research", British Journal of Management, Vol. 27, Issue 4, pp. 836-852.

32. Shimpi, Jayant and Manjare, Sagar O. (2019), "Social Media Marketing - Student Admission in Higher Education”, MERC Global's International Journal of Management, Vol. 7, Issue 2, pp. 174-179.

33. Singh, M.K.M.S.; Pandian, A. and Singh, S.K.G. (2015), "International Graduate Students' Experience in Academic Listening Practices in a Malaysian Public University: Challenges and Overcoming Measures", Asia-Pacific Edu Res. Vol. 24, Issue 1, pp. 91-102.

34. Trotman, D. (2006), "Interpreting imaginative life worlds: Phenomenological approaches in imagination and the evaluation of educational practice", Qualitative Research, Vol. 6, Issue 2, pp. 245-247.

35. Wali, A. F. (2018), "Customer relationship management and marketing effectiveness: A comparative consumer study", Paradigm, Vol. 22, Issue 2, pp. 1-24.

36. Wali, A. F. and Nwokah, G.N. (2016), "Understanding customers' expectations for delivering satisfactory and competitive customer experiences", International Journal of Electronic Marketing and Retailing, Vol. 9, Issue 3, pp. 254-268. 
37. Wali, A. F., Uduma, I. A. and Wright, L. T. (2016), "Customer Relationship Management (CRM) Experiences of Business-to-Business (B2B) Marketing Firms in the Mobile Telecommunication Sector with a qualitative approach", Cogent Business and Management, Vol. 3, Issue 1, pp. 1-22.

38. Wali, A. F.; Cyprian, J. and Nkpurukwe, O. I. (2020), "Influences of Social Media Marketing Tools towards Online Purchases: Nuances from Undergraduate Students in Nigeria Public Universities", Paradigm, Vol. 24, Issue 1, pp. 12-30.

39. Wali, A.F. and Andy-Wali, H.A. (2018), "Students as valuable customers: Integrating a social media marketing platform into customer relationship management capabilities for marketing higher education services", Paradigm, Vol. 22, Issue 1, pp. 1-16.

40. Wali, A.F. and Nwokah, N.G. (2017), "Aviation customers' journey, who cares? Managing customer experiences with customer relationship management strategy: Insight into Nigeria customers' perspectives", Journal of Global Scholars of Marketing Science, Vol. 27, Issue 2, pp. 123-135.

41. Wali, A.F. and Wright, L.T. (2016), "Customer Relationship Management and Service Quality Influences in Higher Education”, Journal of Customer Behaviour, Vol. 15, Issue 1, pp. 67-79.

42. Wangenge-Ouma, G. (2008), "Higher Education Marketisation and Its Discontents: The Case of Quality in Kenya", Higher Education, Vol. 56, Issue 4, pp. 457-471.

43. Young, J. E.; Williamson, M. I. and Egan, T. G. (2016), "Students' reflections on the relationships between safe learning environments, learning challenges and positive experiences of learning in a simulated GP clinic", Adv in Health Sci. Educ., Vol. 21. pp. 63-77.

44. Zou, T.X.P.; Mickleboroughb, N.C.; Hoc, S.S.M. and Yip, S.Y.W. (2015), "Students as learning experience designers: the effect of student-driven approaches in a Hong Kong study", International Journal of Pedagogies and Learning, Vol. 10, Issue 3, pp. 179-193. 